\title{
ETHNOMEDICINAL, PHYTOCHEMICAL, AND PHARMACOLOGICAL ASPECTS OF GENUS ACANTHUS
}

\section{REKHA BORA ${ }^{1}$, PARTHA PRADIP ADHIKARI ${ }^{*}$, AJIT KUMAR DAS ${ }^{1}$, NANJIAN RAAMAN ${ }^{3}$, GAURI DUTT SHARMA ${ }^{4}$}

${ }^{1}$ Laboratory of Ethnobotany and Medicinal Plants Conservation, Department of Ecology and Environmental Science, Assam University, Silchar 788011, India, ${ }^{2}$ Laboratory of Natural Product and Synthetic Organic Chemistry, Department of Chemistry, Assam University, Silchar 788011, India and Genoine Research Laboratory Pvt. Ltd., Subhash Nagar, Karimganj 788710, Assam, India, ${ }^{3}$ Center for Advanced Studies in Botany, University of Madras, Guindy Campus, Chennai 600025, India, ${ }^{4}$ Department of Life Science and Bioinformatics, Assam University, Silchar 788011, India and Bilaspur Vishwavidyalaya, Bilaspur 495001, Chhattisgarh, India

Email: dr.parthaadhikari@gmail.com

Received: 03 Sep 2017 Revised and Accepted: 02 Nov 2017

ABSTRACT

Acanthus (family Acanthaceae) is a genus of the major group angiosperms (flowering plants) comprising more than 29 species widely distributed in the tropical and subtropical region. The aim of this review is to offer thorough scientific information on ethnomedicinal uses, phytochemical, and pharmacological activities of the plant species belonging to the genus Acanthus. Numerous traditional uses of the genus have been supported in this article from the results, and executed by the extracts and/or pure compounds obtained from pharmacological studies will provide a single platform to help future researches on the genus Acanthus. Furthermore, ethnomedicinal evaluation using fractions or isolation of medicinal principles was extensively explored by databases like Google, Google Scholar, and Science Direct at the same time.

Keywords: Acanthus, Acanthaceae, Ethnomedicinal uses, Phytochemistry, Pharmacology, Medicinal principles

(C) 2017 The Authors. Published by Innovare Academic Sciences Pvt Ltd. This is an open access article under the CC BY license (http://creativecommons.org/licenses/by/4.0/) DOI: http://dx.doi.org/10.22159/ijpps.2017v9i12.22386

\section{INTRODUCTION}

The word 'Acanthus' is originated from the Greek word 'Acantha' meaning thorn or thistle signifies sensitive leaves [1]. Most of the species are shrubs or perennial herbs with terminal or axillary, uninterrupted spikes; flower with lower lip only; calyx 4-lobed with larger posterior and anterior lobes; corolla tube short, horny; elongate 3-lobed lip and with 4 exerted stamens, inserted at top of corolla tube [2]. The genus exhibits some mangrove species which are known to survive in the most antagonistic environment which makes this genus as inimitable taxa among all true mangrove genera that represent both terrestrial species and true mangrove. Thus, researchers grow attractive reason to assemble attention for the study of the genus and also to understand the origin and evolution of mangrove species. The distribution of the species of the genus Acanthus has been represented in the fig. 1 .

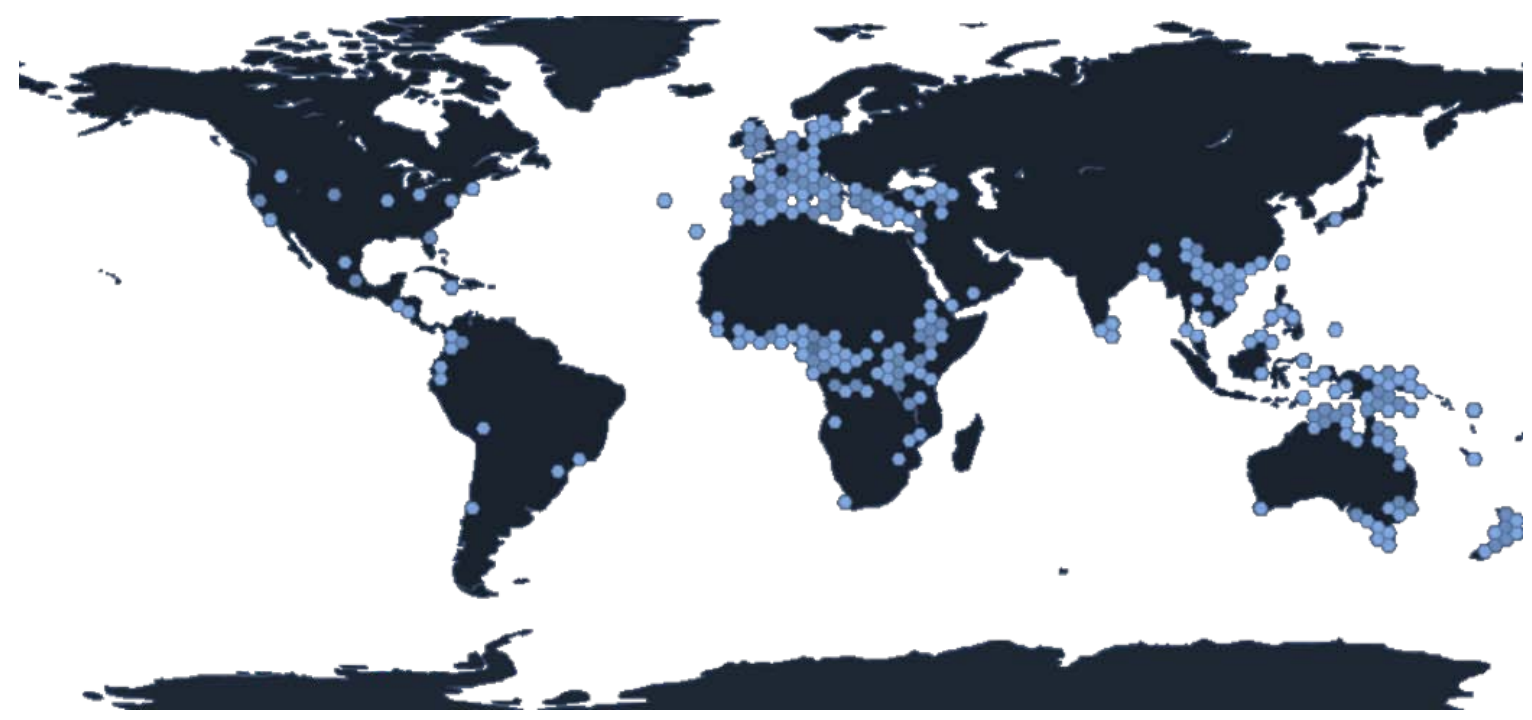

Fig. 1: The distribution of the species of the genus Acanthus (Maps are not to scale)

Description of the genus

The genus Acanthus L. is consist of about 29 representative species geographically distributed mostly in the tropical and subtropical region of the world [3]. Total 28 genera from 20 families represent $c$. a. 70 true mangroves species among these the genus Acanthus represents five mangrove species $e . g$. A. ebracteatus, $A$. illicifolius, $A$ volubilis, $A$. latisepalus and $A$. montanus [4-5]. However, Tomlinson and Yang et al. reported only three mangrove species and c. a. 27 terrestrial species [6-7]. In India, only 6 species of the genus are 
available; A. ebracteatus Vahl, A. ilicifolius L., A. leucostachyus Wall. ex Nees, A. carduaceus Griff., A. mollis L., A. volubilis Wall. Out of these 6 species A. ilicifolius and A. leucostachyus are extremely medicinal and A. leucostachyus Wall. ex Nees, A. carduaceus Griff., A. mollis $\mathrm{L}$. are terrestrial species [8]. Asia and Australia represent the paramount variety and distribution of mangrove species [1] Therefore, the genus is unique among all true mangrove genera were both true mangrove and terrestrial members are obtainable. The two sub species A. ebracteatus subsp. ebracteatus and $A$. ebracteatus subsp. ebarbatus of $A$. ebracteatus which are endemic to Australia [1]. Moreover, both subspecies are detached by few key morphological features i.e. leaf shape, stem spines, flower color and hairiness etc. [1]. In our previous study, the genus was reported with one known species; A. leucostachyus from North East India which was originally established by Wallich in his Numerical List of Dried Specimens (Cat. No. 2512) on the basis of the collection made by F. De Silva from Sylhet District of Bangladesh [8]. But in the worksheet of [9], higher plant diversity in Pakke Wildlife Sanctuary and Tiger Reserve in East Kameng District of Arunachal Pradesh revealed another member of the genus. A. ilicifolius L., a shrub was available in those areas, medicinal use still unknown and least concern at the international union for conservation of nature (IUCN) status [10]. While in the same checklist A. leucostachys Wall. was mentioned as a herb. Ethnomedicinal uses in cut and wound and anti-inflammatory activity was also revealed and evaluated at IUCN status [10]. A. leucostachyus is a terrestrial species present in the rainforest at 600 to $1200 \mathrm{~m}$ above the sea level and bounds to South to Southeast Asia which has the same geographical distribution and same environmental support as the analogous mangrove species. These unique features have made the species more eccentric which have the possibilities to exemplify the phylogenetic aspects of the true mangrove species of the fascinating genus Acanthus [7, 11]. Some of the important species of the genus have described below.

\section{A. leucostachyus Wall. Ex Nees}

Common name: Mishisala (Barman); Mussali (Riang); Sam-sikal (Khasi), Sam-Khatchi (Meghalaya). A. leucostachyus is an unbranched herb height reach up to $90 \mathrm{~cm}$, erect; stem brown, ca $4 \mathrm{~mm}$ in diam, hairy; abaxially glabrescent or brown pubescent along veins, petiole $\sim 0.8-2.5 \mathrm{~cm}$; leaf blade elliptic, secondary veins $\sim 5-8$ on each side of midvein and netted near margin, oblanceolate, or lanceolate, 9-23 × 2-4.5 cm, margin slightly spinose dentate occasionally unnoticeably dentate or irregularly entire, ovate-lanceolate, base rounded to subcordate, adaxially glabrous, tertiary veins inconspicuous, apex acute. Inflorescences fatal thorns, top severe to acuminate; bracteoles lanceolate to oblanceolate, abaxially pubescent, base rounded, palmately veined, apex rounded with a short tip; calyx $c a 2 \mathrm{~cm}$, pubescent; corolla white, $c a 2.1 \mathrm{~cm}$, villous; lobes orbicular, ca $5 \times 5 \mathrm{~mm}$, apex emarginated, margins apically spikey, ca 1-2 $x \sim 0.2-0.4 \mathrm{~cm}$, rachis grayish pubescent; base rounded, margin entire and ciliate. Staminal filaments $c a \sim 8 \mathrm{~mm}$, upper pair curved, glabrous. Ovary $c a \sim 3 \mathrm{~mm}[8]$.

Distribution: The plant is distributed in India Bangladesh (Sylhet), China (Yunnan), Myanmar, Laos, Thailand, and Vietnam. Specimen examination, date, and place of collection of the plant in Bhutan and North East India has been enlisted in table 1.

Table 1: List showing the specimens of Acanthus leucostachyus examined in the Bhutan and North East India [8]

\begin{tabular}{|c|c|c|}
\hline Specimen examined by & Date of collection & Place of collection \\
\hline U. N. Kanjilal & 01.10 .1908 & Nambor Reserve Forest, Assam \\
\hline S. R. Sharma & 07.03.1932 & Nongkhlaw Forest, West Khasi Hills, Meghalaya \\
\hline N. L. Bor & 01.01 .1934 & Aka Hills, Arunachal Pradesh \\
\hline S. R. Sharma & 23.03.1936 & Umsaw, East Khasi Hills, Meghalaya \\
\hline N. L. Bor & March, 1937 & Sibsagar, Hollongpar, Assam \\
\hline G. K. Deka & 22.02.1938 & Shella, East Khasi hills, Meghalaya \\
\hline G. K. Deka & 03.02.1939 & Powai, Tinsukia, Assam \\
\hline G. Panigrahi & 25.05 .1957 & Garbhanga Reserve Forest, Kamrup, Assam. \\
\hline R. S. Rao & 01.09.1957 & Katakhal Reserve Forest, Hailakandi, Assam \\
\hline G. Panigrahi & 22.10 .1960 & Doomdooma Reserve Forest, Tinsukia, Assam \\
\hline G. Panigrahi & 09.03 .1962 & Dullong Reserve Forest, Lakhimpur, Assam \\
\hline D. B. Deb & 23.01.1963 & Kheitum, Lushai Hills Mizoram, \\
\hline R. M. Dutta & 12.07.1963 & Vawmbuk to Thalthlang, Mizoram \\
\hline N. P. Balakrishnan & 14.03.1965 & Jashigong to Yangtsi, Eastern Bhutan, Butan \\
\hline J. Joseph & 14.05.1965 & Nongpoh,Meghalaya, and Noonmati-Barholng, Assam \\
\hline D. M. Verma & 22.05.1968 & Chalohowa, Kananadi, North Lakhimpur, Assam \\
\hline N. P. Balakrishnan & 21.11.1969 & Jaintia Hills, $16 \mathrm{~km}$ from Khleihriat on road to Sonapur, Meghalaya \\
\hline A. K. Das & 14.02 .2002 & Goawara forest, Assam \\
\hline R. Bora and A. K. Das & 05.02 .2012 & Loharbond, Cachar, Assam \\
\hline J. Sarma and S. Baruah & 04.03 .2013 & Gibbon Wildlife Sanctuary, Jorhat, Assam \\
\hline J. Sarma and S. Baruah & 12.04 .2013 & Lakhipathar Area of Upper Dihing Reserve Forest under Digboi Forest Division, Assam \\
\hline
\end{tabular}

Habitat and Ecology: Grow shady places association with other plants like Thottea tomentosa (Blume) Ding Hou and Borreria hispida (L.) K. Schm. etc. [8].

Phenology: March-September

Specimen examined: Specimens of A. leucostachyus Wallich examined in the Bhutan and North East India by various workers in different times $[8,12,13]$.

Status: The plant was reported wrongly as endemic to Eastern Himalaya [13-14].

\section{A. ilicifolius $\mathrm{L}$}

Common names: Holy leaved acanthus, holy mangrove, holy leaved acanthus and sea holy (Eng.), Harkukanta (Hind.), Harkucha kanta (Beng.), Holechudi (Kan.), Payinachulli (Mal.), Kaludaimulli (Tam.), Alasyakampa, Alchi (Tel.).
The plant is a shrub, height up to $3 \mathrm{~m}$ green, light green or purple, stem thick, branched, roots rarely above ground leaves simple, opposite, lanceolate to broadly lanceolate, leaf margin spiny/dentate, leaf tip acute, petiole low length $c a 0.5-2 \mathrm{~cm}$ long, inflorescences terminal [15].

Distribution: A. ilicifolius true mangrove species distributed in tropical Asia and Africa, through Malaya to Polynesia grown in the many of the foreshore areas $[1,16]$. The plant is also reported to grow in Bangladesh $[17,18]$. In India, it is reported from the east (the large area of mangrove forest, the Sunderbans) and west seashore and Andamans and a northeastern state, Meghalaya [1,17].

Habitat and Ecology: Generally it is found on river banks or low marshland areas of mangrove forests and its surroundings above the high tide mark [1].

Phenology: February-May. 
Specimen examined: India, Andaman and Nicobar Islands, South Andaman, Shoal Bay Creek (P. Ragavan, PBL 30965 and 30966) [15].

\section{A. ebracteatus Vahl-Vahl}

It is a shrub up to $2 \mathrm{~m}$ tall, branched, axial spines downward facing, stem thick, grey tint, roots rarely above ground, broadly elliptic to lanceolate, $\sim 10-20 \times 3-6 \mathrm{~cm}$, leaves simple, opposite, leaf tip acute to obtuse with or without spiny; petiole length low ca $\sim 0.5-1.5 \mathrm{~cm}$ inflorescence terminal; ovary bilocular; style surrounded by stamens [15].

Distribution: India to tropical Australia, Southeast Asia, and the western Pacific islands. In Southeast Asia plant has found in Cambodia, Myanmar, the Philippines, Vietnam, Malaysia, Singapore, Indonesia and Papua New Guinea; in India, it has recorded in Kerala, Puducherry, and ANI [15].

Habitat and Ecology: Grow in landward ends of mangroves over the high tide mark and in inner mangroves.

Phenology: Throughout the year.

Specimen examined. India, Andaman and Nicobar Islands, South Andaman, Sippighat (P. Ragavan, PBL 30969 and 30970) [15].

\section{Acanthus volubilis wall}

Plant is a twisted shrub up to $\sim 2-4 \mathrm{~m}$ tall; stem slim, soft, green, branched, axial spines lacking; roots rarely above ground/prop roots on lower parts of reclining stem; leaves simple, opposite, spines absent, juicy, elliptic/oblong-lanceolate, leaf tip acute to obtuse with spin, leaf margin spines lacking, petiole low length ca 0.5-2 cm long, green; inflorescence terminal; style surrounded by stamens; ovary bilocular [15].

Distribution: South to Southeast Asia i.e. Sri Lanka and the Andaman Islands, to Myanmar, Indonesia, Cambodia, Malaysia, Singapore, Thailand and Papua New Guinea. In India, the plant has found in Odisha, ANI, and Sundarbans [15].

Habitat and Ecology: Grown in landward edges of mangroves up to the high tide mark.

Phenology: March-June.

Specimen examined: India, Andaman and Nicobar Islands, South Andaman, Shoal Bay Creek (P. Ragavan, PBL 30969 and 30970) [15].

\section{Acanthus mollis L.}

Synonyms: A. Hispanicus Lou., A. latifolius E. Goez., A. longifolius Poir., A. lusitanicus Auct, A. niger Mill., A. platyphyllus Murb., A. spinosissimum Host.

\section{Traditional uses}

A. ilicifolius also named as "Holy Mangrove" is used as an ethnomedicinal plant in many countries. In Malaysia the plant leaf used to heal rheumatism, neuralgia and poison arrow wounds; in Bangladesh, leaves are used in the treatment of cancer [18]; in Malaysia, seeds of this plant and A. ebracteatus Vahl. Consumed for curing urolithiasis; in India, the root is utilized to treat coughs and asthma; in Thailand, the fresh bark is applied as an antiseptic [19].

Moreover, the plant is also used in asthma, diabetes, dyspepsia, hepatitis, leprosy, paralysis, ringworm, rheumatism, skin problems, snakebite, leucorrhoea, leukemia etc. [19, 20], dropsy [21]; different plant parts, fruit, leaf, bark, and root are used in healing of asthma, diabetes, hepatitis, inflammation, and rheumatism [22-25]; leaves are applied in snake bite [26], consumed as blood purifier [19]; root used in leucorrhoea [27]; different plant parts useful to treat rheumatism, asthma, paralysis, psoriasis and leucorrhoea [28].

A. leucostachyus is another ethnomedicinal plant belongs to this genus. This plant has also been employed in treatment of various diseases like; the leaves of the plant used in fever and toothache [29]; leaf paste is applied externally in cuts and wounds; pest of leaves are prescribed to be applied externally on cancerous tumor by different tribes of Cachar district of Assam [12, 30]; paste of leaves combined with the extract of tuber of Allium sp. and leaves of Thunbergia sp. is applied externally for swelling, fever, toothache [31]; seed, sap and leaves are used in treatment of allergy, headache, hair tonic, boil, eczema and worms [32]. This plant is also used as traditional medicine by Naga tribe of North East India [33]. Moreover, the plant is used by Derois tribe of India in preparation of Sujen, a rice beer along with other plants like Alpinia malaccensis, Costus speciosus etc. [34].

A. montanus (Nees.) T. Anders leaves are reported to be practiced in curing cough, pneumonia, and fever by Mount Cameroon region, Africa [35]. While, the fruit of A. ebracteatus utilized as a blood purifier, leaf paste is applied in a dressing of burns, roots in snakebite and also used in pain caused by wounds and the seeds are used as anthelminthic [36]. 170 genes of $A$. ebracteatus are recognized which are engrossed in response to salt stress [37].

\section{Phytochemistry}

Investigation phytochemical study of the genus Acanthus indicated that phytochemical study has been extensively done on the true mangrove species; A. ilicifolius, beside this work no phytochemical isolation has been performed on this genus.

\section{Phytochemical screening}

Phytochemical study of $A$. ilicifolius done by Raut and Khan [38] emphasized the presence of some important chemical constituents like triterpenoids, alkaloids, saponins glycosides, flavonoids, steroids etc. Ralf and Gerd [39] study also specify the presence of terpenoids, alkaloids, flavonoids, phenols, coumarins. Flower extracts disclose the occurrence of alkaloids, terpenoids, saponins, phenolics, flavonoids, tannins but the absence of steroids [40]. Other study reveals that the plant possesses alkaloids, steroids, tannins, flavonoids and reducing sugar but saponins and gums are absent in crude methanol extract [27].

Govindasamy and Arulpriya [41] also showed that plant leaves contain with alkaloids, phenol, steroids, protein, resins, steroids, tannins, terpenoids, cardiac glycosides, carbohydrates, saponins, glycosides, sugars, and catechol.

\section{Compound isolation}

Wu et al. [42-43] obtained two aliphatic glycosides, ilicifolioside B and ilicifolioside C. Some lignan glycosides, $(+)$-syringaresinol- $O-\beta$ D-glucopyranoside, $(+)$-lyoniresinol $3 \alpha-0-\beta$-D-glucopyranoside, $(+)$ lyoniresinol $2 \mathrm{a}-\mathrm{O}-\alpha-\mathrm{D}$-galactopyranosyl-3a-O- $\beta$-D-glucopyranoside, $(+)$-lyoniresinol 3a-0- $\alpha$-D-galactopyranosyl-(1-6)- $\beta$-D-gluco-pyranoside, (-)-lyoniresinol $3 \alpha-0-\beta$-D-glucopyranoside [51, 43, 57]; fatty acid derivatives, $\beta$-sitosterol octadecanoate, octadecanoic acid, octacosanol, palmitic acid, stigmasterol octadecanoate, tetracosanol [48]; triterpenoids, lupeol and oleanolic acid and ursolic acid [4445] were reported from the same species.

Besides these diverse classes of phytochemicals such as alkaloids, fatty acids, glycosides, lignans, triterpenoid, coumaric acid etc. various derivatives have been isolated and characterized from different extracts like Hexane, chloroform, ethanol, methanol of $A$. ilicifolius, illustrated in table 2 with their structures, pubchem ID's and relevant citations.

\section{Pharmacology}

The pharmacological study has been extensively performed on $A$. ilicifolius among the species of this genus. This study revealed that $A$. ilicifolius has significant bioactivities like, antioxidant and cytotoxic activity [26, 55], antinociceptive activity [56], anti-inflammatory activity [23, 26], anti-osteoporotic activity [57], hepatoprotective activity [26,58], chemopreventive activity [21]; leishmanicidal, tumour reducing and anticancer activities $[26,58,59,60]$; antileishmanial, antiulcer, antimicrobial, and osteoblastic, activities [26]. Moreover, Firdaus et al. found in their study that flower extract of the plant also has good cytotoxic effects [40]; Smitha et al. showed the anticancer activity of ethyl acetate extract of on two cell lines PA1 and MCF-7 [61]. 
Adhikari et al.

Int J Pharm Pharm Sci, Vol 9, Issue 12, 18-25

Table 2: Compounds isolated from Acanthus ilicifolius

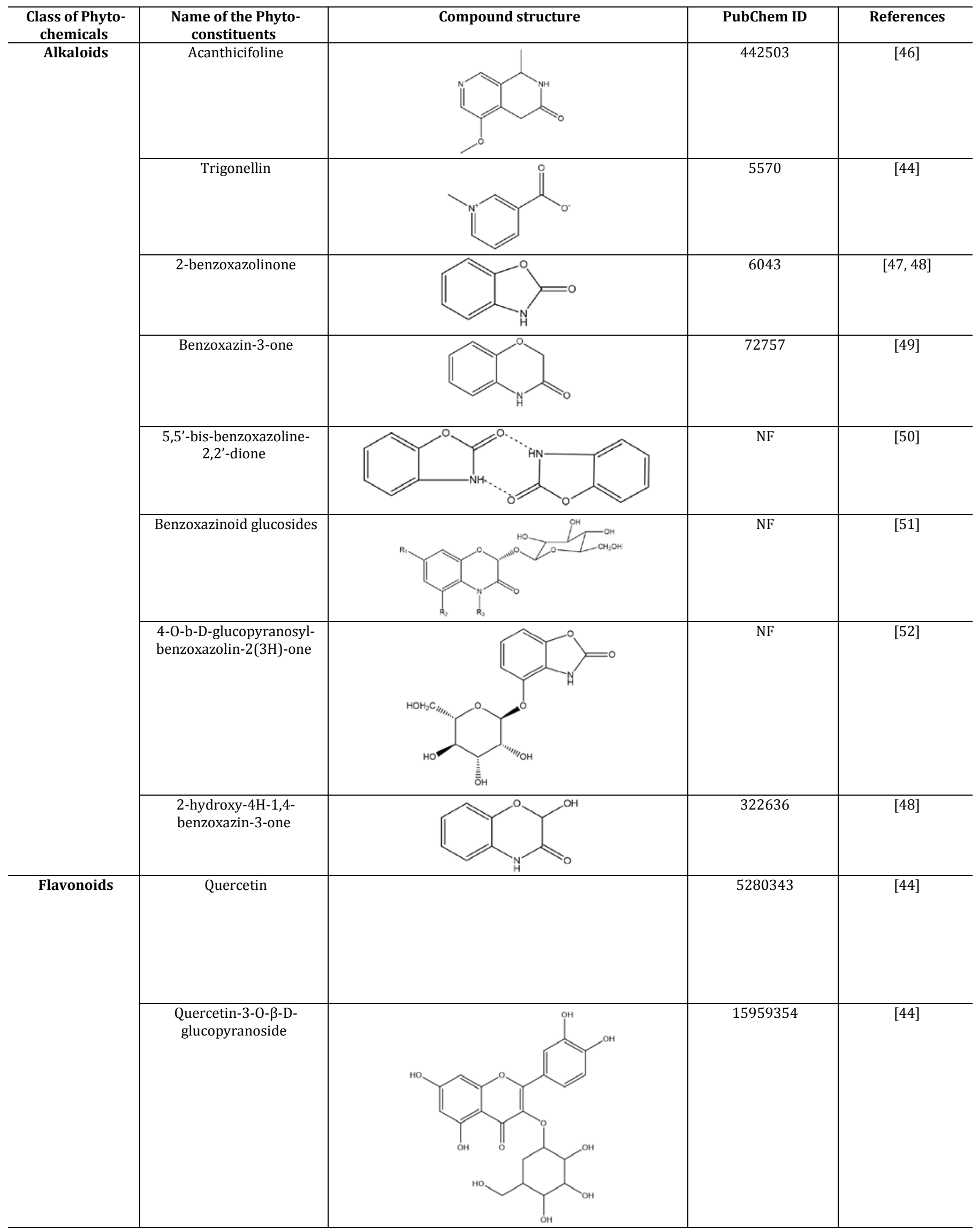




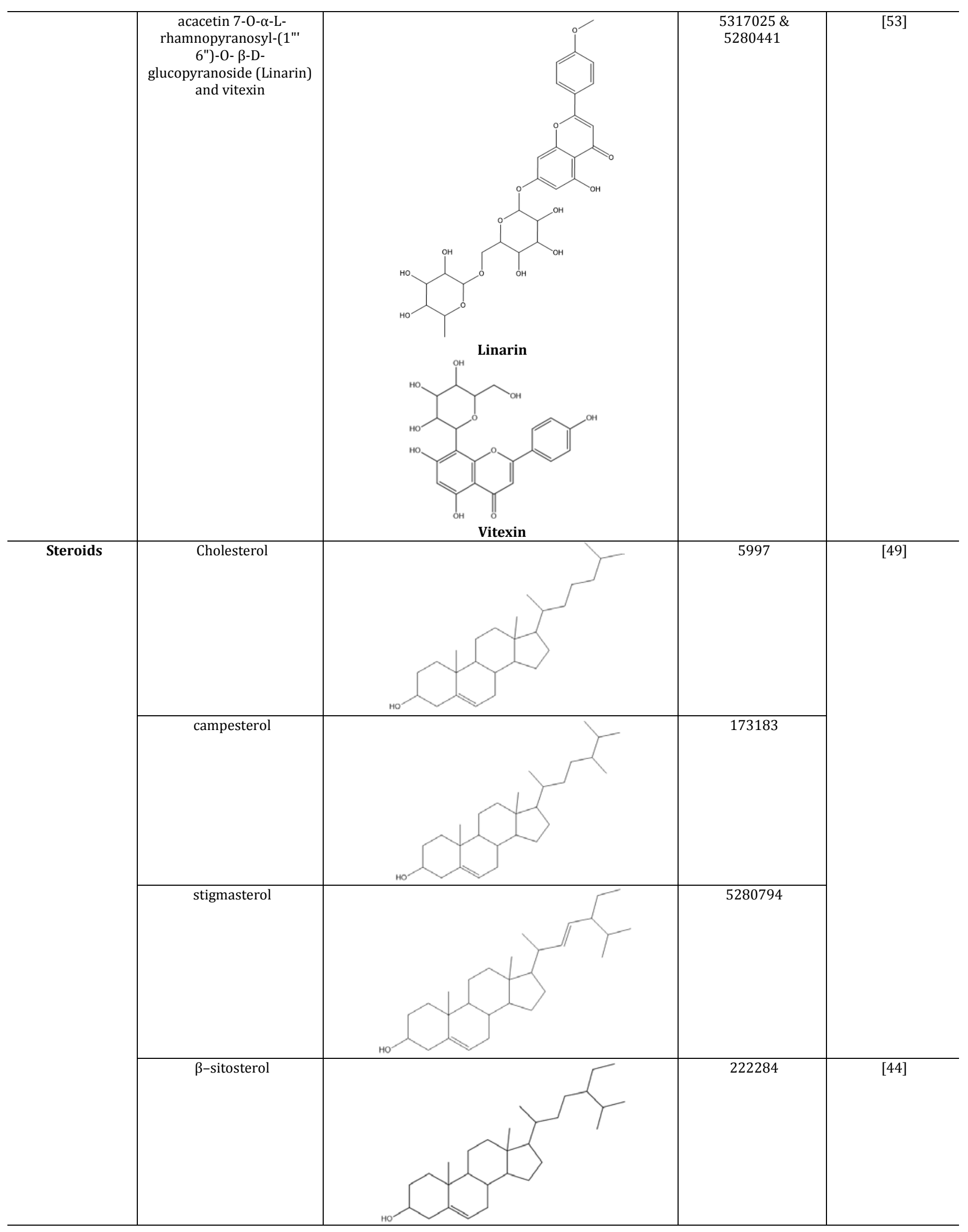




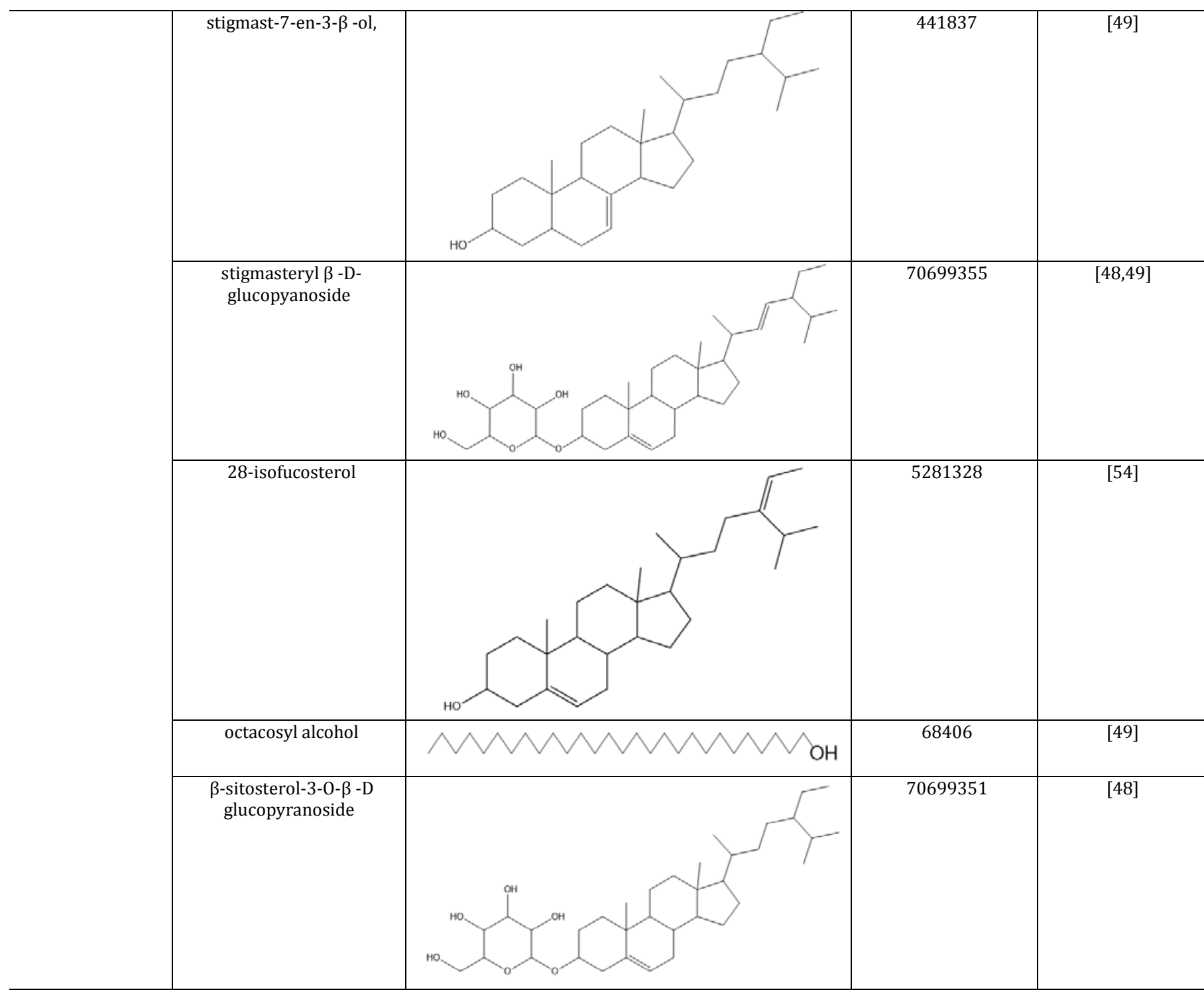

NF: Not Found

\section{Antioxidant activity}

Firdaus et al., [40] have scrutinized the antioxidant properties of $A$. ilicifolius by the DPPH scavenging assay. The assay was conducted on total five extracts (acetone, methanol, acetone 70\%, methanol $80 \%$ and water) of flowers and found that methanol extract showed highest antiradical efficiency (141.30\%), while water extract of showed lowest $(0.0037 \%)$ among the extracts. Dey et al. [27] confirmed the antioxidant effects of the methanol extract of the plant. DPPH assay has been adopted for evaluation of the free radical scavenging activity of the extract by preparing ten different concentrations starting from $500 \mu \mathrm{g} / \mathrm{ml}$ to $0.98 \mu \mathrm{g} / \mathrm{ml}$ using serial dilution technique where $\mathrm{IC}_{50}$ was recorded to be $5.1 \mu \mathrm{g} / \mathrm{ml}$. Moreover, the antioxidant activity of the fractions and isolated compounds of the plant has also been reported [58-60].

Polysaccharides isolated from the plant also showed significant radical scavenging activity [62]; Flavonoids and phenolic compounds of A. ilicifolius displayed their good antioxidant activity on the animal model [63].

\section{Cytotoxic activity}

Firdaus et al., [40] analyzed the cytotoxic of the flower extracts of $A$. ilicifolius on the brine shrimp lethality. The results exhibited methanol extract has lowest $\mathrm{LC}_{50}$ value $(22 \mu \mathrm{g} / \mathrm{ml})$ while water extract showed the highest value at $10 \mu \mathrm{g} / \mathrm{ml}$ among the extracts. Dey et al. [27] have tested the cytotoxic activity of a methanolic crude extract of the plant where it has found that the extract exhibited a significant cytotoxic activity with the $\mathrm{LC}_{50}$ value at 60 $\mu \mathrm{g} / \mathrm{ml}$ and $\mathrm{LC}_{90}$ value at $120 \mu \mathrm{g} / \mathrm{ml}$.

\section{Antimicrobial activity}

Antimicrobial activity of alcohol, butanol and chloroform extract (10 $\mathrm{mg} / \mathrm{ml}$ ) of both leaves and roots of the plant exhibited significant activity against all microbes, $B$. subtilis, $P$. vulgaris, $P$. aeruginosa, $S$. aureus, C. albicans, A. niger, and A. fumigatus. The experiment was followed by agar cup plate method that unveils the leaves were more active than that of roots where ampicillin used as a standard for bacteria and clotrimazole for fungi. Chloroform extract of leaf showed the highest zone of inhibition that was measured $\sim 26 \mathrm{~mm}$ against the fungus $C$. albicans. But butanol extract of leaf extract displayed lowest $\sim 08 \mathrm{~mm}$ against the bacterium S. aureus [64].

Govindasamy and Arulpriya [41] studied antimicrobial activity of against seven skin infection causing microbes, methicillin resistance $S$. aureus (MRSA), L. plantarum, $S$. pyogenes, $S$. epidermis, C. albicans, P. aeruginosa, and T. rubrum. In this test four extract of the leaf has been examined where chloroform extract showed the highest activity against all microbes (except $S$. epidermis and L. plantarum). 
Three extracts, ethanol, methanol and aqueous of leaf, stem, and root of the plant has used for the activity. The cub-plate method used to detect the efficiency of the plant against the eleven bacterial strains Escherichia coli, Bacillus, megaterium. Lactobacillus plantarum, Salmonella paratyphi B, Shigella dycentreae, Streptococcus mutans, Klebsiella pneumoniae, Aspergillus flavus, Staphylococcus albus, and Lactobacillus acidophilus and one fungus C. albicans. Ethanol and methanol extract showed more or less same activity and methanol extract indicated significantly more effective than the aqueous extract. Maximum zone of inhibition noticed on aqueous extract of root and methanol extract of the leaf as $17 \mathrm{~mm}$ against the same bacterium, $S$. albus [26].

Rao et al. [65] examined the antimicrobial activity of methanol, ethanol, and ethyl acetate extracts of flower, seed, leaf, and root of the plant by the well-diffusion method. Microbes like Vibrio harveyi,
Aeromonas hydrophila, and E. coli were taken for the test, results direct the highest activity observed on ethyl acetate seed extract against $V$. harveyi. Dey et al. [27] observed the antibacterial activity of a methanolic crude extract of the plant by ten gram-negative and six-gram positive bacteria, unfortunately, no activity was witnessed for the crude methanol extract.

\section{Anticancer activity}

Smitha et al. [61] studied the anticancer activity of ethyl acetate extract of leaf and root extract of the plant on two cell lines, MCF-7 and PA-1. The plant is more effective on PA-1 and the result has recommended that at $50 \mu \mathrm{g} / \mathrm{ml}$ ratio is adequate to inhibit the cancer cells. Moreover, the result has also unveiled that the extract is slightly cytotoxic to both of the cell lines. The antimicrobial and antioxidant activity of $A$. ilicifolius is depicted in table 3 .

Table 3: Antimicrobial and antioxidant activity of Acanthus ilicifolius

\begin{tabular}{llll}
\hline Plant parts & Solvent used for extraction/isolated compound & Activity agaist \\
\hline Leaf and root & Hexane, chloroform, and methanol & Antibacterial, antifungal \\
Leaf and root & Benzoate and phenylethanoid derivatives & Antimicrobial \\
Leaf and root & 2-Benzoxazolinone 4 and benzoxazinium derivatives & Antimicrobial, antifungal and insecticidal & [66] \\
Leaf and root & Methanol & Antibacterial & DPPH \\
& & DPPH & [27] \\
Flower & Acetone and methanol & [55] & \\
\hline
\end{tabular}

\section{CONCLUSION}

The plants from the genus Acanthus are broadly scattered in the tropical and subtropical regions of the world. The systematic pharmacological studies on the genus have given remarkable recognition to their ethnomedicinal uses in health care management. The phytochemical studies of the genus Acanthus revealed, isolation of a total of 21 bioactive compounds from A. ilicifolius and were identified with their structures and their respective PubChem ID's were mentioned in this review. Hence, the existence of these bioactive compounds may be explored from other sister species and their different pharmacological properties may also be compared. Numerous pharmacological studies using different types of extracts or pure phytochemicals of Acanthus species well justified their practice as an ethnomedicine; for example, antioxidant, antimicrobial, cytotoxic and anticancer activities besides its well-known antinociceptive, hepatoprotective, leishmanicidal and osteoblastic properties. Furthermore, scanty and limited toxicity reports on the animal model are presently available, which suggests that detailed toxicological evaluation is needed for different extracts from the various species. Correspondingly, the biological effectiveness should be carried out for the isolated secondary phytochemicals as well, which would definitely authenticate the medicinal claims of the Acanthus genus.

\section{ACKNOWLEDGMENT}

$\mathrm{RB}$ is thankful to Assam University, Silchar for institutional fellowship support.

\section{CONFLICTS OF INTERESTS}

All authors have no conflicts of interest to declare.

\section{REFERENCES}

1. Saranya A, Ramanathan T, Kesavanarayanan KS, Adam. Traditional medicinal uses, chemical constituents and biological activities of a mangrove plant, Acanthus ilicifolius Linn.: a brief review. Am Eur J Agric Environ Sci 2015;15:243-50.

2. Jiaqi H, Yunfei D, Wood JRI, Daniel TF. Acanthaceae. In: AlShehbaz. eds. Flora of China. Science Press, Beijing, and Missouri Botanical Garden Press: St. Louis, U. S. A; 2002;19:369-477.

3. Mabberley DJ. Mabberley's Plant-Book: A portable dictionary of plants, their classification and uses. $3^{\text {rd }}$ Edition. Cambridge University Press: Cambridge; 2008.

4. Duke N, Ball M, Ellison J. Factors influencing biodiversity and distributional gradients in mangroves. Glob Ecol Biogeogr Lett 1998; $7: 27-47$
5. Duke NC. Australia's mangroves: the authoritative guide to Australia's Mangrove Plants, University of Queensland; 2006.

6. Tomlinson P. The botany of mangroves. Cambridge tropical biology series. Cambridge, New York, USA: Cambridge University Press; 1986.

7. Yang Y, Yang S, Li J, Deng Y, Zhang Z, Xu S, et al. Transcriptome analysis of the holly mangrove acanthus ilicifolius and its terrestrial relative, acanthus leucostachyus, provides insights into adaptation to intertidal zones. BMC Genomics 2015;16:1-12.

8. Bora R, Das AK, Sharma GD. Ecology and taxonomic study Acanthus leucostachyus Wall. ex Nees: a promising ethnomedicinal plant from Assam. J Non-Timber Forest Prod 2013;20:95-8.

9. Tag H, Jeri L, Mingki T, Tsering J, Das AK. Higher plant diversity in pakke wildlife sanctuary and tiger reserve in east kameng district of arunachal pradesh: checklist-I. Pleione 2012;6:149-62.

10. IUCN. Guidelines for Using the IUCN Red List Categories and Criteria. Version 7 (August 2008). Prepared by the Standards and Petitions Working group of the IUCN-SSC Biodiversity Assessments Subcommittee, Huntingdon Road, Cambridge, UK; 2008. p. 1-70.

11. Hu J, Deng YF, Wood JRI, Daniel TF. Acanthaceae. Flora of China 2011;19:369-477.

12. Das AK, Dutta BK, Sharma GD, Hajra PK. Medicinal plants of southern Assam, deep publication, New Delhi-110063; 2010.

13. Baruah S, Sarma J, Roy H, Borthakur SK. Notes on two interesting angiosperms from Assam, India. Pleione 2013;7:401-5.

14. Barik SK, Haridasan K, Lakadong NJ. Medicinal plant resources of Meghalaya: Endemic threat status and consumption pattern. Envis Forestry Bull 2007;7:17-26.

15. Ragavan P, Saxena A, Mohan PM, Jayaraj RSC, Ravichandra K. Taxonomy and distribution of species of the genus Acanthus (Acanthaceae) in mangroves of the Andaman and Nicobar Islands, India. Boidversitas 2015;16:225-36.

16. Wang Y, Zhu H, Tam NFY. Polyphenols, tannins and antioxidant activities of eight true mangrove plant species in South China. Plant Soil 2014;374:549-63.

17. Amirul I, Saifuzzaman M, Ahmed F, Mustafizur R, Nazneen AS, Naher K. Antinociceptive activity of methanolic extract of Acanthus ilicifolius Linn. leaves. Turk J Pharm Sci 2012;9:51-60.

18. Nur KA, Mizanur R, Biswas S, Nasir A. Appraisals of bangladeshi medicinal plants used by folk medicine practitioners in the prevention and management of malignant neoplastic diseases. Int Scholarly Res Notices 2016;1-12. Doi:10.1155/2016/7832120.

19. Supriya B, Vijayakumar K, Subramanian N, Kumar D. Medicinal values of Putranjiva roxburghii-a review. Int J Curr Pharm Res 2017;9:1-4. 
20. Bandaranayake WM. Bioactivities, bioactive compounds and chemical constituents of mangrove plants. Wetlands Ecol Manag 2002;10:421-52.

21. Chakraborty T, Bhuniya D, Chatterjee M, Rahaman M, Singha D, Chatterjee BN, et al. Acanthus ilicifolius plant extract prevents DNA alterations in a transplantable Ehrlich ascites carcinoma-bearing murine model. World J Gastroenterol 2007;13:6538-48.

22. Bandaranayake WM. Traditional and medicinal uses of mangroves. Mangroves Salt Marshes 1998;2:133-48.

23. Kumar KT, Gorain B, Roy DK, Samanta SK, Pal M, Biswas P, et al. Anti-inflammatory activity of Acanthus ilicifolius. J Ethnopharmacol 2008;120:7-12.

24. Sundaram R, Ganesan R, Murugesan G. In vitro antiplasmodial activity of spiro benzofuran compound from mangrove plant of Southern India. Asian Pac J Trop Med 2011;5:358-61.

25. Govindasamy C, Kannan R. Pharmacognosy of mangrove plants in the system of unani medicine. Asian Pac J Trop Dis 2012;2(Suppl 1):S38-S41.

26. Ganesh S, Vennila JJ. Screening for antimicrobial activity in Acanthus ilicifolius. Arch Appl Sci Res 2010;2:311-31.

27. Dey A, Raihan SM, Sariful Islam HM, Hamiduzzaman M, Monjur-AlHossain ASM. Phytochemical screening and the evaluation of the antioxidant, cytotoxic and antimicrobial properties of Acanthus ilicifolius (Family: Acanthaceae). Int Res J Pharm 2012;3:153-6.

28. Kirtikar KR, Basu BD. Indian medicinal plants. Vol. 8. $1^{\text {st }}$ ed. Dehradun: International Book Distributors; 2001.

29. Jeeva S, Mishra BP, Venugopal N, Kharlukhi L, Laloo RC. Traditional knowledge and biodiversity conservation in the sacred groves of Meghalaya. Indian J Traditional Knowledge 2006;5:563-8.

30. Das AK, Dutta BK, Sharma GD. Medicinal plants used by different tribes of Cachar district, Assam. Indian J Traditional Knowledge 2008; 7:446-54.

31. Singh OP, Tiwari BK, Lynser MB, Bharali S. Environmental accounting of natural resources of meghalaya: phase i-land and forest resources (Technical Report). the central statistical organization, the government of India, New Delhi; 2008.

32. Manikandaselvi S, Vadivel V, Brindha P. Review on ethnobotanical studies of nutraceutical plant: Capparis spinosa L. (Caper). Asian J Pharm Clin Res 2016;9:21-4.

33. Pfoze NL, Kehie M, Kayang H, Mao AA. Estimation of ethnobotanical plants of the Naga of North East India. J Med Plants Stud 2014;2:92-104.

34. Ahuja U, Ahuja SC. Alcoholic rice beverages. In: Encyclopaedia of the history of science, technology, and medicine in non-western cultures. Springer Netherlands, Dordrecht; 2014. p. 1-7.

35. Fongod AGN, Modjenpa NB, Veranso MC. Ethnobotany of acanthaceae in the mount cameroon region. J Med Plants Res 2013; 7:2707-13.

36. Pradhan SD, Palei CN, Rath PB, Swain KK, Kar S. A new addition of mangrove species Acanthus ebracteatus Vahl. (Acanthaceae) to the mangrove flora of Bhitarkanika National Park, Odisha, India. Int J Innov Appl Res 2016;4:28-31.

37. Nguyen PD, Ho CL, Harikrishna JA, Wong MC, Rahim RA. Generation and analysis of expressed sequence tags from the mangrove plant, Acanthus ebracteatus Vahl. Tree Genet Genomes 2006;2:196-201.

38. Raut S, Khan S. Phytochemical fingerprinting of Acanthus ilicifolius L. Adv Plant Sci 2012;25:749-53.

39. Ralf W, Gerd L. Chemical composition of the mangrove holly Acanthus ilicifolius (Acanthaceae)-review and additional data. Frankfurt Main 2008;38:31-7.

40. Firdaus M, Prihanto AA, Nurdiani R, Widodo N. Antioxidant and cytotoxic activity of Acanthus ilicifolius flower. Asian Pacific J Trop Biomed 2013;3:17-21.

41. Govindasamy C, Arulpriya M. Antimicrobial activity of Acanthus ilicifolius: skin infection pathogens. Asian Pac J Trop Dis 2013,3:180-3.

42. Wu J, Zhang $\mathrm{S}$, Huang J, Xiao Q, Li Q, Long L, et al. New aliphatic alcohol and (Z)-4-coumaric acid glycosides from Acanthus ilicifolius. Chem Pharm Bull 2003;51:1201-3.

43. Wu J, Zhang $\mathrm{S}$, Xiao $\mathrm{Q}, \mathrm{Li} \mathrm{Q}$, Huang J, Long $\mathrm{L}$, et al. Phenylethanoid and aliphatic alcohol glycosides from Acanthus ilicifolius. Phytochemistry 2003;63:491-5.
44. Minocha PK, Tiwari KP. Chemical constituents of Acanthus ilicifolius Linn. Pol J Chem 1980;54:2089-90.

45. Minocha PK, Tiwari KP. A triterpenoid saponin from roots of Acanthus ilicifolius. Phytochemistry 1981;20:135-7.

46. Tiwari KP, Minocha PK, Masood M. Acanthicifoline-a new alkaloid from Acanthus ilicifolius. Pol J Chem 1980;54:857-8.

47. Murty MSR, Solimabi Kamat SY. Isolation of 2-benzoxazolinone from acanthus ilicifolius. Indian J Pharm Sci 1984;46:218-9.

48. Zhong LJ, Huang MY, Zhang JG, Li GW, Zhang YH. Study on the chemical constituents from Acanthus ilicifolius Linn. var. xiamenensis. Chin J Marine Drugs 2012;31:23-8.

49. Kokpol U, Chittawong V, Miles DH. Chemical constituents of the roots of Acanthus ilicifolius. J Nat Prod 1986;49:354.

50. D'Souza L, Wahidulla S, Mishra PD. Bisoxazolinone from the mangrove Acanthus ilicifolius. Indian J Chem Sect B 1997;36B:1079-81.

51. Kanchanapoom T, Kamel MS, Kasai R, Picheansoonthon C, Hiraga Y, Yamasaki K. Benzoxazinoid glucosides from Acanthus ilicifolius. Phytochemistry 2001;58:637-40.

52. Huo C, An D, Wang B, Zhao Y, Lin W. Structure elucidation and complete NMR spectral assignments of a new benzoxazolinone glucoside from Acanthus ilicifolius. Magn Reson Chem 2005;43:343-5.

53. Wu J, Zhang S, Xiao Q, Li Q, Huang J, Long L, et al. Megastigmane and flavone glycosides from Acanthus ilicifolius. Pharmazie 2003;58:363-4

54. Clarke A, Gleeson P, Jermyn M, Knox R. Characterization and localization of lectins in lower and higher plants. Funct Plant Biol 1978;5:707-22.

55. Muhamad F, Prihanto AA, Nurdiani R. Antioxidant and cytotoxic activity of Acanthus ilicifolius flower. Asian Pac J Trop Biomed 2013;3:17-21.

56. Islam MA, Saifuzzaman M, Ahmed F, Rahman MM, Sultana NA, Naher K. Antinociceptive activity of Methanolic extract of Acanthus ilicifolius L. leaves. Turk J Pharm Sci 2012,9:51-60.

57. Van Kiem P, Quang TH, Huong TT, Nhung TH, Cuong NX, Van MC, et al. Chemical constituents of Acanthus ilicifolius L. and effect on osteoblastic MC3T3E1 cells. Arch Pharm Res 2008;31:823-9.

58. Babu BH, Shylesh BS, Padikkala J. Antioxidant and hepatoprotective effect of Acanthus ilicifolius. Fitoterapia 2001;72:272-7.

59. De Carvalho, PB Ferreira EI. Leishmaniasis phytotherapy. Nature's leadership against an ancient disease. Fitoterapia 2001;72:599-618.

60. Babu BH, Shylesh BS, Padikkala J. Tumour reducing an anticarcinogenic activity of Acanthus ilicifolius. J Ethnopharmacol 2002;79:27-33.

61. Smitha RB, Madhusoodanan PV, Prakashkumar R. Anticancer activity of Acanthus ilicifolius Linn. from chettuva mangroves, Kerala, India. Int J Bioassays 2014;3:3452-5.

62. Zhang T, Tian Y, Jiang B, Miao M, Mu W. Purification, preliminary structural characterization and in vitro antioxidant activity of polysaccharides from Acanthus ilicifolius. LWT-Food Sci Technol 2014;56:9-14.

63. Asha KK, Mathew S, Lakshmanan PT. Flavonoids and phenolic compounds in two mangrove species and their antioxidant property. Indian J Mar Sci 2012;41:259-64.

64. Bose S, Bose A. Antimicrobial activity of Acanthus ilicifolius (L.). Indian J Pharm Sci 2008;70:821-3.

65. Rao SM, Teja G, Sirisha IR, Rao PY. Screening of antimicrobial activity of mangrove plant Acanthus ilicifolius on shrimp and fish pathogens. Asian J Plant Sci Res 2015;5:1-3.

66. Pradeep V, Khajure, Rathod JL. Antimicrobial activity of extracts of Acanthus ilicifolius extracted from the mangroves of from the mangroves of Karwar coast karnataka. Recent Res Sci Technol 2010;2:98-9.

67. Ravikumar S, Raja M, Gnanadesigan M. Antibacterial potential of benzoate and phenylethanoid derivatives isolated from Acanthus ilicifolius L. leaf extracts. Nat Prod Res 2012;26:2270-3.

68. Das A, Ahmed AB. Natural permeation enhancer for transdermal drug delivery system and permeation evaluation: a review. Asian J Pharm Clin Res 2017;10:7-11. 